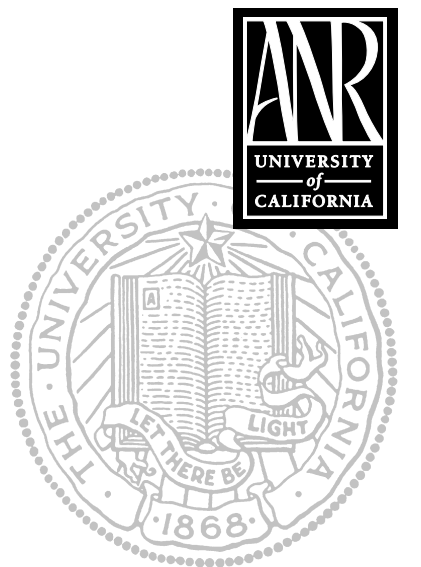

UNIVERSITY OF

CALIFORNIA

Division of Agriculture and Natural Resources

http://anrcatalog.ucdavis.edu

\title{
Feeding Rice Straw to Cattle
}

DANIEL J. DRAKE, University of California Cooperative Extension Livestock Farm Advisor, Siskiyou County; GLENN NADER, University of California Cooperative Extension Livestock and Natural Resources Farm Advisor, Sutter/Yuba/Butte Counties; LARRY FORERO, University of California Cooperative Extension Livestock and Natural Resources Farm Advisor, Shasta and Trinity Counties.

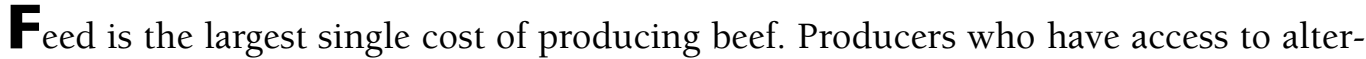
native feeds often have economic advantages due to the lower costs of production. However, alternative feeds can present challenges due to variable consistency, variable supply, potential toxicants, and unusual composition. Rice straw, a by-product of the rice grain industry in Northern California, is a potential alternative feed for cow and calf producers. Increasing regulations and restrictions on burning rice straw has stimulated interest in using it for other purposes, including cattle feed.

Because rice straw has limited nutritive value (low crude protein and digestibility), it should be used only as a replacement for part of the forage in a ration. It should not be used as a complete ration. Studies of feeding rice straw have shown mixed results, depending on the quality of the straw and how it was used in the ration (see Garret 1978; Garrett and Dunbar 1992; Hull et al. 1972; Nader 1999, 2000; Nader et al. 1998). Poorer animal performance has usually occurred when rice straw was the only feed.

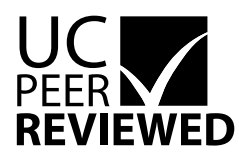

Management by rice growers to produce higher-quality rice straw permits cattle producers to use rice straw as a feed. In this way, straw, a by-product for the rice grower, does not become an air-quality hazard when burned and is converted instead into high-quality human food.

\section{KEYS TO MAKING RICE STRAW WORK IN YOUR CATTLE FEEDING OPERATION}

- Make sure the rice straw was baled within 10 days of harvest.

- Test the rice straw for crude protein and ADF, preferably before purchase.

- Determine what other feeds or supplements will have to be provided to meet the nutritional needs of animals.

- Compare costs of feeding options or alternatives.

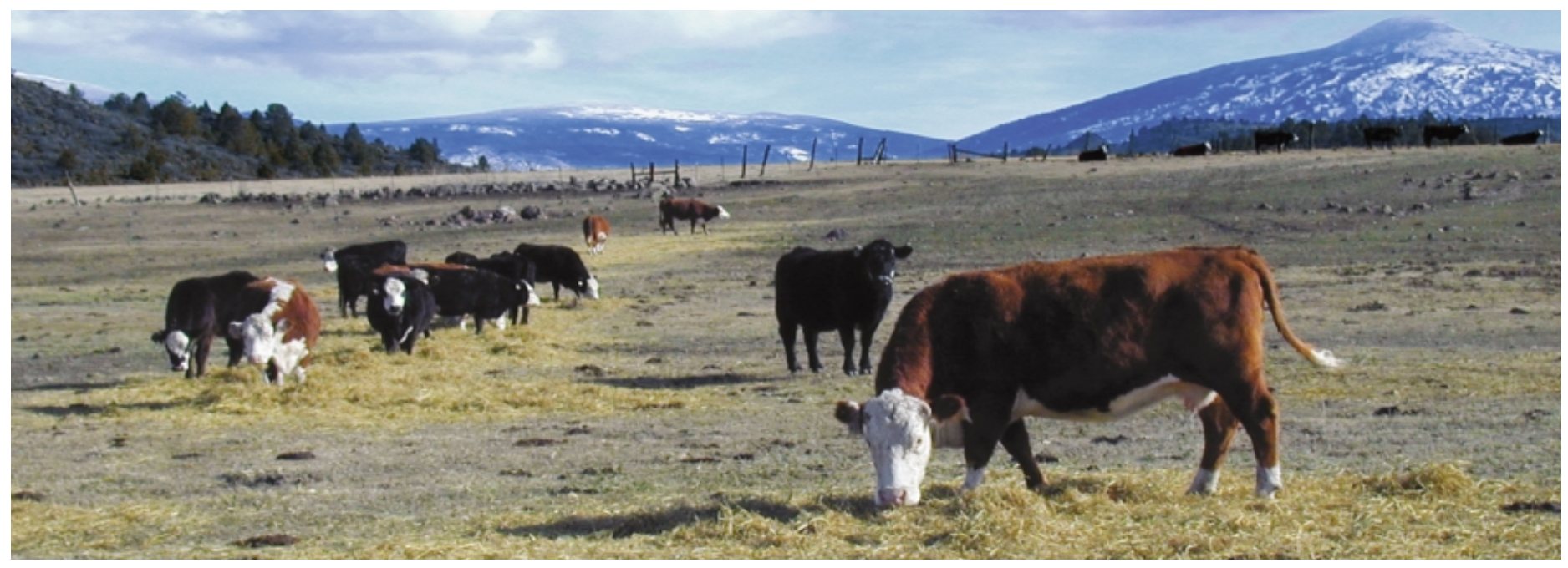




\section{CHALLENGES IN FEEDING RICE STRAW}

- Palatability. Cattle are more likely to eat rice straw if the time between rice harvest and straw baling is short. In addition, rice straw has a slight pubescence (small hairs) that cows may take some time to adapt to.

- Low digestibility. Rice straw has a very high silica content (8 to 14\%) compared with alfalfa hay (1 to $2 \%$ ). Silica is indigestible and decreases digestibility of the feed. This is particularly true in the rice leaves, which contain the highest levels of silica. This high silica level combined with other mineral compounds produces an average ash content of $17 \%$ for rice straw as compared with 7 to $8 \%$ for alfalfa.

- Low protein. The crude protein of 2 to $7 \%$ on a dry matter basis in rice straw requires protein supplementation to meet the nutritional requirements of most cattle.

- High in oxalates. Oxalates in rice straw decrease the absorption of calcium. This may not present a problem in the intermountain region of California, where producers supplement with calcium-rich alfalfa hay, but it should be considered in other areas of the state.

\section{VARIABILITY IN STRAW QUALITY}

The quality of rice straw varies tremendously. Data collected from samples has found that crude protein $(\mathrm{CP})$ varies from 2 to 7 percent and acid detergent fiber (ADF) varies from 41 to 56 percent on a dry matter (DM) basis (moisture-free basis) (table 1). Crude protein is estimated by determining the total nitrogen and multiplying by 6.25 . ADF is a laboratory method of determining a fiber fraction that can assist in predicting the digestibility of a feed: straw with lower ADF values tends to be more digestible. Energy can be estimated from ADF by calculating total digestible nutrients (TDN) (see box below). Rice straw of 2 to 3 percent crude protein on a dry matter basis should not be used for cattle feed, as its forage value is generally less than the cost of baling and hauling, and it may cause poor animal health or death.

\section{Converting a lab value for rice straw ADF to TDN}

$\mathrm{TDN}=85.7-(0.756 \times \mathrm{ADF})$

Example:

Rice straw with ADF of $48 \%$

$\mathrm{TDN}=85.7-(0.756 \times 48)=49.4 \%$ 
Table 1. Laboratory analysis of rice straw samples

\begin{tabular}{cccccc}
\hline & CP & ADF & TDN & Calcium & Phosphorus \\
\cline { 2 - 4 } Sample & & \multicolumn{3}{c}{ Percent by weight, DM basis } & \\
\hline 1 & 2.9 & 56.7 & 43 & 0.49 & 0.09 \\
2 & 3.4 & 56.1 & 43 & 0.42 & 0.07 \\
3 & 3.4 & 55.2 & 44 & 0.43 & 0.07 \\
4 & 4.0 & 42.1 & 54 & 0.28 & 0.12 \\
5 & 4.1 & 41.4 & 54 & 0.24 & 0.12 \\
6 & 4.1 & 43.0 & 53 & 0.24 & 0.11 \\
7 & 4.2 & 47.5 & 50 & 0.31 & 0.07 \\
8 & 4.4 & 44.9 & 52 & 0.51 & 0.16 \\
9 & 4.6 & 47.1 & 50 & 0.32 & 0.11 \\
10 & 4.6 & 52.3 & 46 & 0.55 & 0.12 \\
11 & 4.7 & 48.3 & 49 & 0.39 & 0.07 \\
12 & 4.7 & 53.1 & 46 & 0.38 & 0.16 \\
13 & 4.8 & 48.8 & 49 & 0.38 & 0.07 \\
14 & 4.8 & 49.3 & 48 & 0.31 & 0.07 \\
15 & 4.8 & 51.7 & 47 & 0.44 & 0.14 \\
16 & 5.0 & 52.0 & 46 & 0.48 & 0.09 \\
17 & 5.1 & 53.0 & 46 & 0.33 & 0.07 \\
18 & 5.2 & 48.6 & 49 & 0.30 & 0.08 \\
19 & 5.4 & 49.6 & 48 & 0.42 & 0.09 \\
20 & 5.6 & 44.9 & 52 & 0.22 & 0.10 \\
21 & 5.9 & 50.7 & 47 & 0.40 & 0.09 \\
22 & 7.5 & 42.8 & 53 & 0.71 & 0.14 \\
\hline
\end{tabular}

Note: $\mathrm{CP}=$ crude protein; $\mathrm{ADF}=$ acid detergent fiber; $\mathrm{TDN}=$ total digestible nutrients. Samples are sorted from lowest to highest CP. TDN is estimated from ADF for all samples as: TDN $=85.7-(0.756 \times A D F)$.

Research has not been able to thoroughly explain the reasons for variability in the nutritive value of rice straw, but some of the important factors are

- days between harvest and baling

- nitrogen fertilization management of the rice

- geographic location of the rice field in the rice growing region

Rice producers have generally considered straw as waste product and have baled it at their convenience after harvest. The Holzapfel Ranch in Willows has successfully used rice straw as cattle feed since 1943. One key to their success is that they bale it within 1 to 3 days after the rice harvest. This improves the palatability (smell, flavor, and color) of the product, and research suggests that baling it soon after rice harvest prevents the substantial decrease in nutritive quality that occurs postharvest (fig. 1).

Figure 1. Acid detergent fiber (ADF) on a dry matter (DM) basis of rice straw increases with days after grain harvest. Rice straw should be baled within 10 days of harvest.

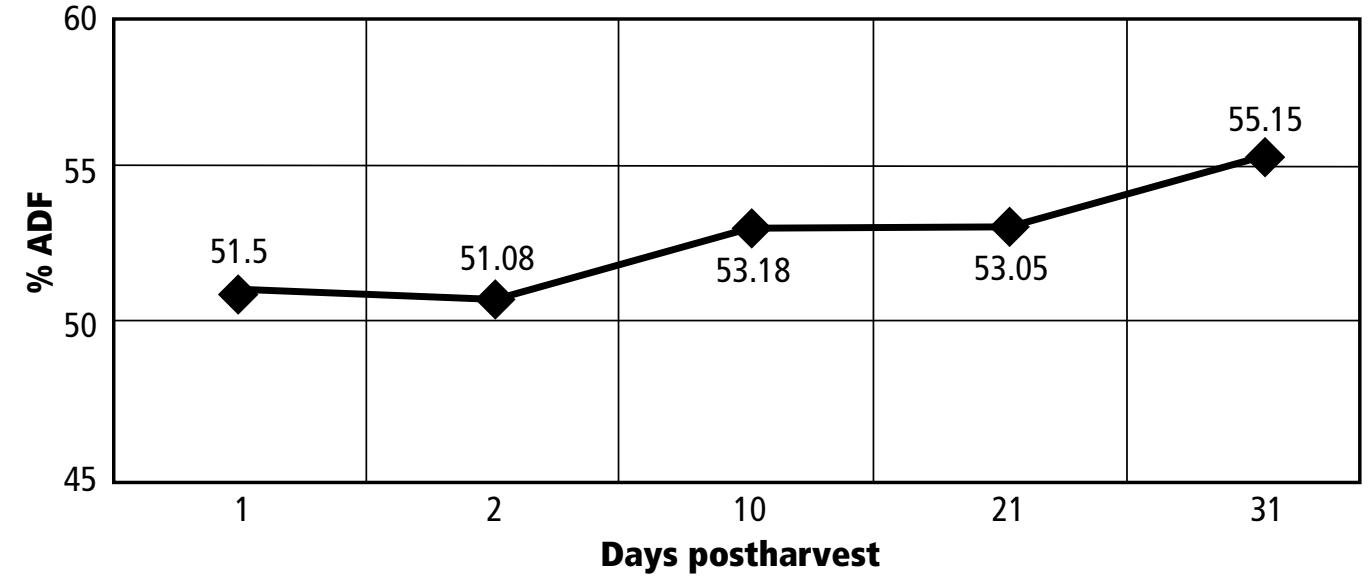


Figure 2. Crude protein content on a dry matter (DM) basis of rice straw increases as more nitrogen is applied to the growing rice crop.
Research has shown that higher nitrogen fertilization of the rice plants yields higher crude protein in the straw (fig. 2). This is not intended as a recommendation that rice growers should increase nitrogen fertilization for improved forage quality. However, cattle producers can use this information to select straw from higher-fertility fields for forage. Research has also shown that the location of the rice field results in different forage quality, even with the same varieties and nitrogen fertilization. For example, the same variety with identical nitrogen management grown in Chico or Yuba City will have different straw quality. More research is planned to determine the causes of this variation by location.

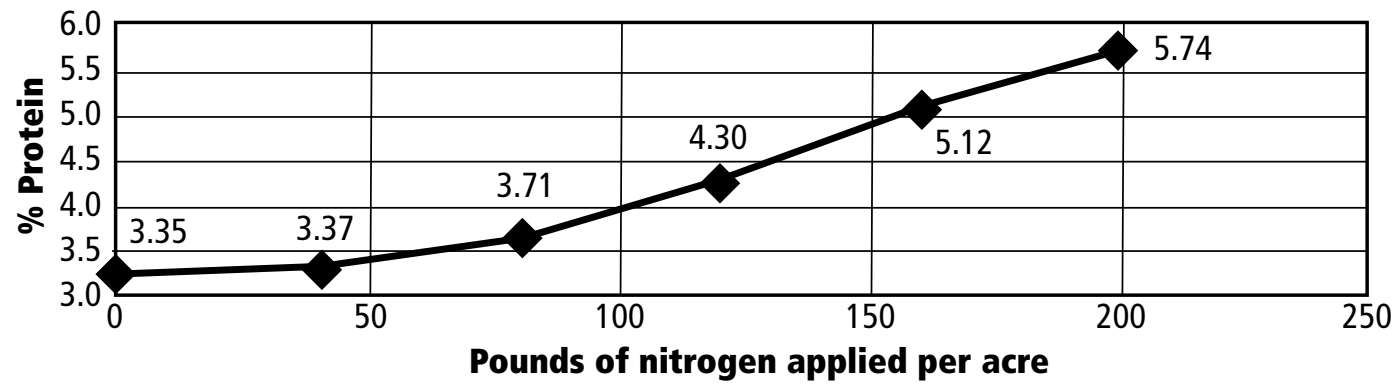

Frequently, cattle producers have little or no idea of the quality of the straw that they purchase. Their purchases may be arranged by brokers or truckers who transport rice straw or with rice growers hundreds of miles away. Due to the unknown quality and potential variability of the rice straw, it is very important to have it sampled and analyzed for quality (CP, ADF, and moisture), preferably before purchase and transportation. Testing rice straw allows the maximum amount of straw to be fed and, even more important, prevents rations that reduce cattle performance.

Suggested forage value criteria for rice straw are:

- Crude protein: $4.5 \%$ or higher on a dry matter basis

- ADF: $50 \%$ or lower on a dry matter basis

\section{COLLECTING RICE STRAW SAMPLES}

Samples obtained with a coring tool for sampling alfalfa hay are adequate for testing. Rice straw is usually available in larger bales, which requires a different sampling method than with smaller 2- or 3-twine bales. Larger bales should have 4 to 5 cores taken from the end or face of about 25 percent of the bales. Typical truck and trailer loads should be sampled from 5 different bales, taking 4 to 5 cores from each bale. With smaller bales, take a single core from the center of about 20 different bales for each lot. Store the samples (all of the cores from a single lot of hay) in a 1- or 2-quart ziplock-type plastic bag. Each bag should be labeled for later identification. The label should include the date, owner, stored location, seller, and any other pertinent information. 


\section{LABORATORY ANALYSIS}

Send straw and feed samples to a commercial laboratory for chemical analysis. Request that the lab determine crude protein, acid detergent fiber (ADF), and moisture (DM); tests for calcium and phosphorus are less critical. Some commercial labs have test packages for feed analysis that are less expensive than the same tests selected separately. Since rice straw is usually fed with other feeds, those feeds should also be tested in a similar manner. The names and locations of commercial laboratories can be found at the University of California Alfalfa Workgroup's "California Alfalfa and Forages" Web site (http://alfalfa.ucdavis.edu/). See the "Forage Quality Info" section (http://alfalfa.ucdavis.edu/subpages/ForageQuality.htm), and then select "2001 Listing of California Recognized Labs (pdf file) to view the online publication 2001 NFTA and California Recognized Labs (http://alfalfa.ucdavis.edu/subpages/ForageQuality/2001CArecognized.pdf).

\section{QUESTIONS TO ASK THE RICE PRODUCER ABOUT THE STRAW}

When considering the purchase of rice straw for livestock feed, it is important to consider the following:

- What are the crude protein, $\mathrm{ADF}$, and moisture levels of the rice straw?

- How many days after harvest was it baled? (Quality decreases with time.)

- What was the nitrogen fertilization level (if CP is not known)? (The higher the better.)

- What percent grain retention is there in the heads? (More grain increases the energy value of the rice straw.)

- Did the harvester have straw choppers? Did it chop the straw in shorter pieces?

- Is there mold in the straw? (Mold may be harmful to cattle.)

- Has the straw been covered or rained on? (Rained-on straw is more likely to be moldy.)

- What size are the bales? (Handling cost per bale?)

- Were herbicides, pesticides, or desiccants applied to the rice that restricts it for livestock feed use?

\section{TAX CREDIT}

A \$15 per ton tax credit for the purchase of California-grown rice straw can be used against the "net tax" of the California state income tax. This program is scheduled to end in 2007. For more information and certification, contact the California Department of Food and Agriculture, Sacramento (Rice Straw Tax Credit Program, Department of Food and Agriculture, 1220 N Street, Rm 409, Sacramento, CA 95814, phone 916-651-7178; Web site http://www.cdfa.ca.gov/exec/aep/rstc_program/rstc.htm).

\section{BACKHAULS TO REDUCE TRANSPORTATION COSTS}

Some areas far from California's rice-growing region produce and transport alfalfa hay for dairies, and backhauls may help reduce the cost of transporting low-quality rice straw. Evaluation of costs of using rice straw as an alternative feed must include transportation costs; in some cases, such as hauls over 250 miles or with difficult roads or handling situations, the cost of hauling may exceed the original cost of the rice straw. When several different feeds are being considered for purchase or availability, ration 
formulating computer programs may be most appropriate for determining whether rice straw can be economically transported (see "Formulating Rations with Rice Straw and Supplements," below).

\section{AMOUNT OF RICE STRAW TO BE USED IN RATIONS}

Several factors determine how much rice straw can be used in a ration, including

- quality of rice straw and other feeds

- nutritional needs of the cattle

- environmental conditions during feeding (temperature, rain, snow, mud, etc.)

- condition of the cattle and expected performance

Based on the nutrient analysis of feeds (table 2) and the nutritional requirements of cattle (table 3), it is possible to develop an overview of the nutritive value of various mixtures of rice straw, hays, and liquid or block supplements. Figures 3, 4, and 5 illustrate crude protein, TDN, and phosphorus levels in rations using 25 or 50 percent rice straw with 4 different hays, and rice straw with low or high rates of molassesbased liquid or block supplements. Table 2 gives the nutrient analysis of the feeds used to obtain the data in these figures; table 3 gives the nutritional requirements of cattle; table 4 gives the nutrient analysis of sample rice straw-hay rations; and table 5 gives the nutrient analysis of sample rice straw-supplement rations. In the figures, liquid or block (molasses-based) supplements were estimated to increase intake of forage by 20 percent, and the efficiency of using nonprotein nitrogen (NPN) was estimated at 50 percent of natural protein. The liquid supplement used in the examples is high in fat and correspondingly high in energy.

Table 2. Nutrient analysis on a dry matter basis of feeds used to obtain data in figures 3,4 , and 5

\begin{tabular}{|c|c|c|c|c|c|c|c|}
\hline \multirow[b]{2}{*}{ Feed } & DM & TDN & CP & $\begin{array}{l}\text { CP from } \\
\text { NPN }\end{array}$ & $\begin{array}{c}\text { Effective } \\
\text { CP }\end{array}$ & Calcium & Phosphorus \\
\hline & \multicolumn{7}{|c|}{ Percent by weight } \\
\hline rice straw & 90 & 44.0 & 4.3 & 0 & 4.3 & 0.21 & 0.08 \\
\hline $\begin{array}{l}\text { grass hay, } \\
\text { average quality }\end{array}$ & 90 & 54.0 & 8.0 & 0 & 8.0 & 0.39 & 0.24 \\
\hline $\begin{array}{l}\text { grass hay, } \\
\text { excellent quality }\end{array}$ & 90 & 58.0 & 12.0 & 0 & 12.0 & 0.39 & 0.24 \\
\hline $\begin{array}{l}\text { alfalfa, nondairy, } \\
\text { quality }\end{array}$ & 90 & 56.0 & 14.0 & 0 & 14.0 & 1.18 & 0.21 \\
\hline $\begin{array}{l}\text { alfalfa, } \\
\quad \text { dairy quality }\end{array}$ & 90 & 61.0 & 16.5 & 0 & 16.5 & 1.18 & 0.21 \\
\hline $\begin{array}{l}\text { liquid } \\
\text { supplement }\end{array}$ & 56 & 93.7 & 44.0 & 25 & 19.0 & 3.00 & 1.50 \\
\hline $\begin{array}{l}\text { block } \\
\text { supplement }\end{array}$ & 96 & 72.0 & 28.0 & 0 & 28.0 & 2.00 & 1.50 \\
\hline
\end{tabular}

Note: $\mathrm{DM}=$ dry matter; $\mathrm{TDN}=$ total digestible nutrients; $\mathrm{CP}=$ crude protein; $\mathrm{NPN}=$ nonprotein nitrogen. Feeds are sorted from lowest to highest effective $C P$. 
Table 3. Nutritional requirements of cattle

\begin{tabular}{|c|c|c|c|c|c|c|}
\hline \multirow[b]{2}{*}{ Cattle } & \multicolumn{2}{|c|}{$\begin{array}{c}\text { DMI, } \\
\text { lb }\end{array}$} & \multirow[t]{2}{*}{ TDN } & \multirow[t]{2}{*}{ CP } & \multirow{2}{*}{$\begin{array}{l}\text { Calcium } \\
\text { M basis }\end{array}$} & \multirow[t]{2}{*}{ Phosphorus } \\
\hline & $\begin{array}{l}100 \% \\
\text { DM basis }\end{array}$ & $\begin{array}{l}90 \% \\
\text { basis }\end{array}$ & & & & \\
\hline cows, dry & 20.8 & 23.1 & 48.8 & 6.9 & 0.19 & 0.19 \\
\hline $\begin{array}{l}\text { cows, average milking, } \\
\text { with calves }\end{array}$ & g, 23.0 & 25.5 & 55.5 & 9.3 & 0.27 & 0.22 \\
\hline $\begin{array}{l}\text { cows, superior milking, } \\
\text { with calves }\end{array}$ & g, 23.8 & 26.4 & 63.7 & 11.5 & 0.36 & 0.26 \\
\hline $\begin{array}{l}\text { heifers, replacement, } \\
\text { just before calving }\end{array}$ & 18.8 & 20.9 & 57.7 & 8.4 & 0.29 & 0.21 \\
\hline $\begin{array}{l}\text { steers, } 600-700 \mathrm{lb}, \\
\text { gaining } 1.0 \mathrm{lb} / \mathrm{day}\end{array}$ & 15.0 & 16.7 & 58.5 & 9.0 & 0.28 & 0.19 \\
\hline $\begin{array}{l}\text { steers, } 600-700 \mathrm{lb}, \\
\text { gaining } 1.5 \mathrm{lb} / \mathrm{day}\end{array}$ & 15.6 & 17.3 & 63.0 & 9.8 & 0.35 & 0.21 \\
\hline $\begin{array}{r}\text { heifers, } 600-700 \mathrm{lb}, \\
\text { gaining } 0.5 \mathrm{lb} / \mathrm{day}\end{array}$ & 14.3 & 15.9 & 56.0 & 8.0 & 0.22 & 0.19 \\
\hline $\begin{array}{r}\text { heifers, } 600-700 \mathrm{lb}, \\
\text { gaining } 1.0 \mathrm{lb} / \mathrm{day}\end{array}$ & 14.3 & 15.9 & 62.0 & 8.6 & 0.27 & 0.20 \\
\hline $\begin{array}{l}\text { steers, } 600-700 \mathrm{lb}, \\
\text { maintenance ration }\end{array}$ & 13.5 & 15.0 & 50.0 & 7.4 & 0.18 & 0.17 \\
\hline $\begin{array}{l}\text { heifers, } 600-700 \mathrm{lb} \text {, } \\
\text { maintenance ration }\end{array}$ & 12.6 & 14.0 & 50.0 & 7.4 & 0.18 & 0.17 \\
\hline
\end{tabular}

Source: National Research Council 1984.

Note: $\mathrm{DMI}=$ dry matter intake; $\mathrm{DM}=$ dry matter; $\mathrm{TDN}=$ total digestible nutrients; $\mathrm{CP}=$ crude protein.

Table 4. Nutrient analysis (DM basis) of rice straw-hay rations used to obtain data in figures 3,4 , and 5 .

\begin{tabular}{lccccc}
\hline & Rice straw & TDN & CP & Calcium & Phosphorus \\
\cline { 2 - 6 } Ration & \multicolumn{5}{c}{ Percent, DM basis } \\
\hline alfalfa (dairy quality) & 25 & 56.8 & 13.4 & 0.94 & 0.18 \\
and rice straw & 50 & 52.5 & 10.4 & 0.70 & 0.15 \\
& & & & & \\
alfalfa (nondairy quality) & 25 & 53.0 & 11.6 & 0.94 & 0.18 \\
and rice straw & 50 & 50.0 & 9.2 & 0.70 & 0.15 \\
grass hay (excellent quality) & 25 & 54.5 & 10.1 & 0.35 & 0.20 \\
and rice straw & 50 & 51.0 & 8.2 & 0.30 & 0.16 \\
grass hay (average quality) & 25 & 51.5 & 7.1 & 0.35 & 0.20 \\
and rice straw & 50 & 49.0 & 6.2 & 0.16 & 0.16 \\
\hline
\end{tabular}

Note: $\mathrm{TDN}=$ total digestible nutrients; $\mathrm{CP}=$ crude protein. 
Table 5. Nutrient analysis of rice straw-supplement rations (percent, DM basis) used to obtain data in figures 3,4 , and 5

\begin{tabular}{|c|c|c|c|c|c|c|}
\hline \multirow[b]{2}{*}{ Ration } & \multirow[b]{2}{*}{$\begin{array}{l}\text { DMI,* } \\
\text { lb }\end{array}$} & $\begin{array}{l}\text { Rice } \\
\text { straw }\end{array}$ & TDN & CP & Calcium & \multirow[t]{2}{*}{ Phosphorus } \\
\hline & & \multicolumn{4}{|c|}{ Percent, DM basis } & \\
\hline \multirow{2}{*}{$\begin{array}{l}\text { block supplement (1 or } 2 \mathrm{lb}) \\
\text { and rice straw (dry cows) }\end{array}$} & $24.8 \dagger$ & 95 & 53.7 & 6.2 & 0.33 & 0.16 \\
\hline & & 90 & 55.1 & 7.4 & 0.42 & 0.23 \\
\hline \multirow{2}{*}{$\begin{array}{l}\text { block supplement ( } 1 \text { or } 2 \mathrm{lb}) \\
\text { and rice straw (cow with calf) }\end{array}$} & $27.4 \ddagger$ & 95 & 59.3 & 6.8 & 0.36 & 0.17 \\
\hline & & 90 & 60.6 & 7.9 & 0.44 & 0.24 \\
\hline \multirow{2}{*}{$\begin{array}{l}\text { liquid supplement (2 or } 4 \mathrm{lb}) \\
\text { and rice straw (dry cows) }\end{array}$} & $24.5 \S$ & 95 & 55.0 & 5.9 & 0.40 & 0.17 \\
\hline & & 90 & 57.2 & 6.6 & 0.55 & 0.25 \\
\hline \multirow{2}{*}{$\begin{array}{l}\text { liquid supplement ( } 2 \text { or } 4 \mathrm{lb} \text { ) } \\
\text { and rice straw (cow with calf) }\end{array}$} & $27.3+\dagger$ & 95 & 60.0 & 6.4 & 0.43 & 0.18 \\
\hline & & 90 & 62.8 & 7.2 & 0.57 & 0.26 \\
\hline
\end{tabular}

Notes:

$\mathrm{DMI}=$ dry matter intake; $\mathrm{TDN}=$ total digestible nutrients; $\mathrm{CP}=$ crude protein.

* DMI was increased 20 percent as a result of the supplement. For comparison, percentages were calculated based on the quantity of nutrients derived from the increased consumption but divided by the nonenhanced DMI (see table 3).

† Percentage calculated on basis of $20.8 \mathrm{lb}$ DMI.

¥ Percentage calculated on basis of $23.0 \mathrm{lb}$ DMI.

$\S$ Percentage calculated on basis of $20.8 \mathrm{lb}$ DMI.

t† Percentage calculated on basis of $23.0 \mathrm{lb}$ DMI. 
Figure 3. Crude protein (CP) levels (100\% DM basis) of 4 different hays combined with 25 or 50 percent rice straw (A) or rice straw with low or high rates of either liquid (2 or $4 \mathrm{lb}$ ) or block (1 or $2 \mathrm{lb}$ ) supplements (B). Nutritional requirements for dry cows, average milking cows, and superior milking cows with calves are shown for comparison to ration levels. Rations with rice straw and various hays satisfy $C P$ requirements of dry cows and average milking cows but do not satisfy CP requirements of superior milking cows. See table 6.
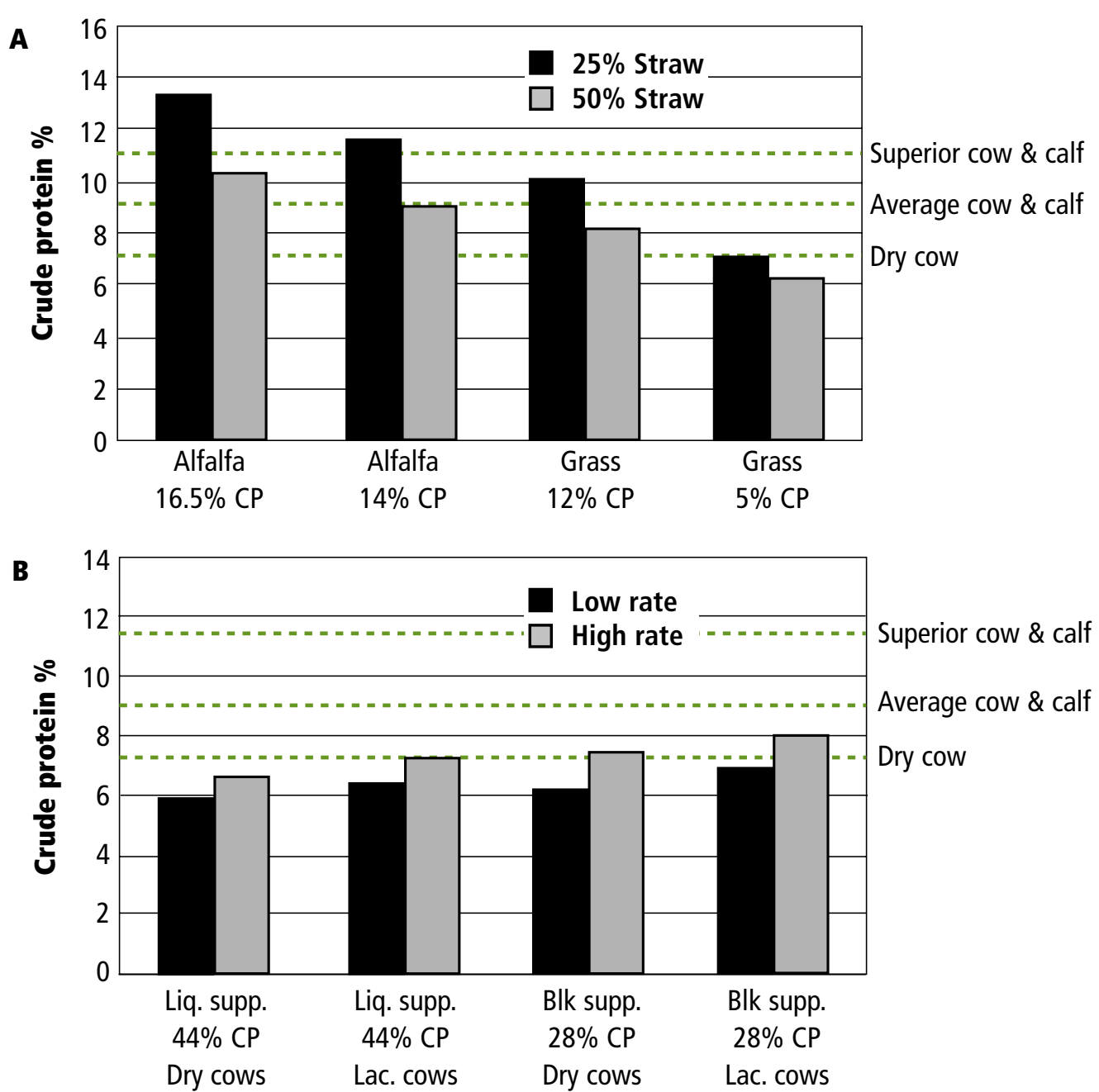

\section{Protein (see figure 3)}

Dry cows. All of the sample hays mixed with 25 or 50 percent rice straw satisfy the crude protein requirements for dry cows, except for grass hay with 50 percent rice straw. Rice straw with block supplements at the higher rate had an adequate crude protein level; at the lower rate, rice straw with liquid or block supplements had an inadequate level of crude protein.

Cows with calves. To satisfy crude protein requirements of average milking cows with calves, rice straw should be restricted to 25 percent of the diet combined with hay of at least 12 percent crude protein. Rice straw could be increased to 50 percent of the ration if alfalfa hay or hay of at least 14 percent crude protein is used as the remainder of the ration. Rice straw for superior milking cows should not exceed 25 percent of the diet, and it should be used only with alfalfa hay of at least 14 percent crude protein. Liquid or block supplements were unable to satisfy crude protein needs at 2 or 4 pounds daily use, respectively.

Steers and heifers. Replacement heifers near calving and 600- to 700-pound steers gaining 1.0 pound per day or heifers gaining 0.5 pound per day have slightly lower crude protein requirements than an average milking cow with calf: use rice straw rations similar to those for an average milking cow with calf. Steers and heifers of a similar weight gaining 1.5 and 1.0 pound per day, respectively, have crude protein requirements slightly lower than a superior milking cow with calf: use rice straw rations similar to those for a superior milking cow with calf. Maintenance crude protein levels for these steers and heifers are similar to those of dry cows: use rice straw rations similar to those for a dry cow. 
Figure 4. Energy measured by TDN levels (100\% DM basis) for 4 different hays combined with 25 or 50 percent rice straw (A) or rice straw with low or high rates of liquid (2 or $4 \mathrm{lb}$ ) or block (1 or $2 \mathrm{lb}$ ) supplements (B). Nutritional requirements for dry cows, average milking cows, and superior milking cows and calves are shown for comparison to ration levels. Rations with some rice straw are adequate in energy for dry cows but need the additional nutrients of dairy-quality alfalfa for lactating cows. See table 6.
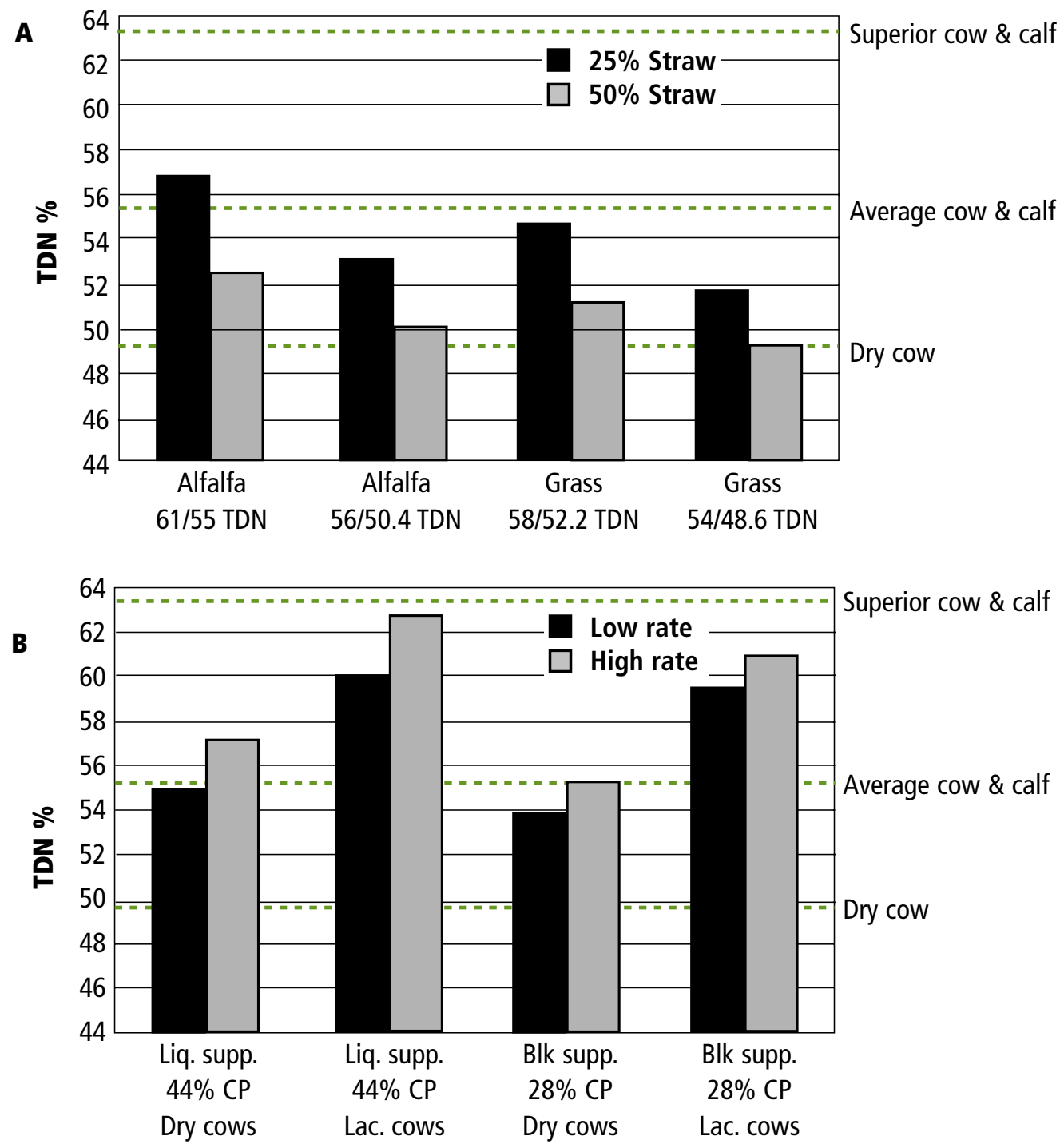

\section{Energy (see figure 4)}

Dry cows. Rations with 50 percent rice straw and any of the sample hays, or rice straw plus liquid or block supplements at the lower or higher rate, can supply the energy needs of dry cows.

Cows with calves. Of the sample hays, only dairy-quality alfalfa with 25 percent rice straw can supply the energy needs of average cows with calves. Rice straw with high rates of liquid (4 lb) or block ( $2 \mathrm{lb}$ ) supplements can also supply the energy levels of average milking cows. Rice straw fed with any hay or supplement cannot supply the energy needs of superior milking cows.

Energy-deficient rations can be fed on a short-term basis, but they will cause cows to lose weight. Milk production on those rations may suffer and re-breeding may be delayed. Energy-deficient cows that continue to lose weight may die from lack of fat and energy reserves.

Steers and heifers. Replacement heifers near calving and 600- to 700-pound steers gaining 1.0 pound per day or heifers gaining 0.5 pound per day have slightly higher TDN requirements than an average milking cow with calf: use rice straw rations similar to those for an average milking cow with calf. Steers and heifers of a similar weight gaining 1.5 and 1.0 pound day, respectively, have TDN requirements about the same as a superior milking cow with calf: use rice straw rations similar to those for a superior cow with calf. 
Figure 5. Phosphorus levels (100\% DM basis) for 4 different hays combined with either 25 or 50 percent rice straw (A) or rice straw with low or high rates of liquid (2 or $4 \mathrm{lb}$ ) or block (1 or $2 \mathrm{lb}$ ) supplements (B). Nutritional requirements for dry cows, average milking cows, and superior milking cows and calves are shown for comparison to ration levels. Rice straw rations usually require phosphorus supplementation. See table 6.
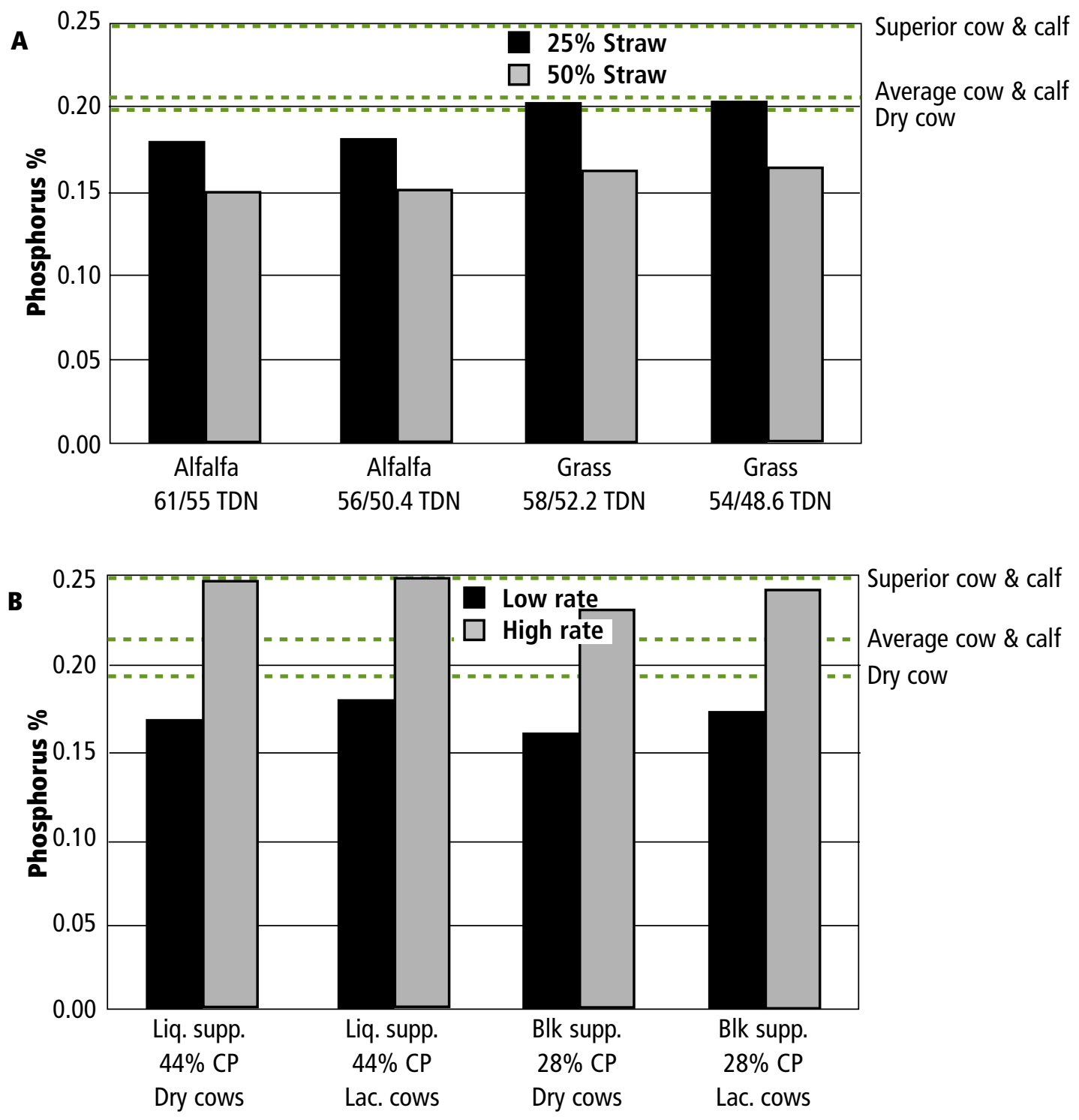

Maintenance energy levels for these steers and heifers are similar to TDN requirements for dry cows: use rice straw rations similar to those for a dry cow.

\section{Calcium and phosphorus}

Calcium levels are generally adequate in rations made up of rice straw and any of the sample hays or supplements (see tables 2 and 3). Rice straw alone is adequate in calcium except as a ration for superior milking cows. Rice straw mixed with hay is deficient or marginally deficient in phosphorus unless grass hay is used (fig. 5). Rice straw fed with higher rates of liquid (4 lb) or block (2 lb) supplements contains sufficient phosphorus for dry cows and average milking cows; superior milking cows, however, require liquid supplements, as block supplements are insufficient. A shortterm dietary deficiency in phosphorus may not be detrimental. However, phosphorus supplements should be considered, especially when feeding rice straw over extended periods or with superior milking cows. 


\section{Ration summary}

- Rice straw generally can comprise about 50 percent of the ration with other hays, or all of the ration plus liquid or block supplements for dry cows.

- Rations with greater amounts of rice straw may result in loss of body weight.

- For cows with calves, rice straw generally should not exceed 25 percent of the ration, and medium- to high-quality alfalfa or high-quality grass hay should comprise the remainder of the diet, or solely rice straw with at least 2 pounds of the tested liquid or block supplement.

- Rice straw is usually not adequate in diets for superior milking cows.

- Extra effort to provide better-quality supplements (higher energy and crude protein) may enhance rice straw rations sufficiently for superior milking cows. Otherwise, reduced performance may result.

- Rice straw rations similar to those that are adequate for dry cows generally provide maintenance (no weight gain or loss) for weaned steers or heifers at about 600 to 700 pounds. For gains of 0.5 pound per day in heifers and 1.0 pound per day in steers, rations similar to those for average milking cows with calves are needed. The rations may be slightly lower in crude protein and higher in TDN. Higher rates of gain, 1.0 pound per day in heifers and 1.5 pounds per day in steers, would require rations similar to superior milking cows with calves.

- Phosphorus and trace mineral supplements are needed, especially for heavier-milking cows.

- Failure to supply required nutrients may result in reduced performance, poor health, or death. Under some circumstances, such as extreme drought, diets of only rice straw may be used for short periods.

Table 6. Ration recommendations for selected cattle

\begin{tabular}{|c|c|}
\hline$\overline{\text { Cattle }}$ & Ration recommendation \\
\hline cows, dry & $50 \%$ rice straw and grass hay or supplement. \\
\hline $\begin{array}{l}\text { cows, average milking, } \\
\text { with calves }\end{array}$ & $\begin{array}{l}\text { Maximum of } 25 \% \text { rice straw and high-quality hay or supplement. Weight loss and } \\
\text { reduced performance may occur. }\end{array}$ \\
\hline $\begin{array}{l}\text { cows, superior milking, } \\
\text { with calves }\end{array}$ & $\begin{array}{l}\text { Rice straw not recommended. With a maximum of } 25 \% \text { rice straw, expect reduced } \\
\text { performance. }\end{array}$ \\
\hline $\begin{array}{l}\text { heifers, replacement } \\
\text { just before calving }\end{array}$ & $\begin{array}{l}\text { Rations similar to superior milking ability cows; crude protein slightly lower and TDN } \\
\text { slightly higher. }\end{array}$ \\
\hline $\begin{array}{l}\text { steers, } 600-700 \mathrm{lb}, \\
\text { gaining } 1.0 \mathrm{lb} / \text { day }\end{array}$ & Similar to average milking cows; crude protein slightly lower and TDN slightly higher. \\
\hline $\begin{array}{l}\text { steers, } 600-700 \mathrm{lb} \text {, } \\
\text { gaining } 1.5 \mathrm{lb} / \mathrm{day}\end{array}$ & $\begin{array}{l}\text { Rice straw not recommended. With a maximum of } 25 \% \text { rice straw, expect reduced } \\
\text { performance. }\end{array}$ \\
\hline $\begin{array}{l}\text { heifers, } 600-700 \mathrm{lb} \text {, } \\
\text { gaining } 0.5 \mathrm{lb} / \text { day }\end{array}$ & Similar to average milking cows; crude protein slightly lower and TDN slightly higher. \\
\hline $\begin{array}{l}\text { heifers, } 600-700 \mathrm{lb} \text {, } \\
\text { gaining } 1.0 \mathrm{lb} / \mathrm{day}\end{array}$ & $\begin{array}{l}\text { Rice straw not recommended. With a maximum of } 25 \% \text { rice straw, expect reduced } \\
\text { performance. }\end{array}$ \\
\hline $\begin{array}{l}\text { steers and heifers, } \\
600-700 \mathrm{lb} \text {, } \\
\text { maintenance ration }\end{array}$ & Similar to dry cows. \\
\hline
\end{tabular}




\section{FEEDING METHODS}

\section{Rice Straw on Crop Aftermath or Stubble}

If crop aftermath, stubble, or residual feed is available, cattle may not eat rice straw readily. As cattle eat the existing crop residues, eventually reducing its availability, they will increase consumption of rice straw. When large amounts of rice straw are fed with small amounts of higher-quality hay, dominant cows may eat most of the higher-quality feeds, causing some cattle to receive a deficient diet.

To help avoid this problem, feed rice straw by itself every other day, with higher quality hay on alternate days. Another option is to feed the rice straw first and the other hay later in the same day; but this requires two trips, which increases feeding costs. Some producers provide several days' supply of rice straw for free-choice consumption, and every day they provide the additional portion of higher-quality hay to satisfy nutritional requirements. University of Nevada studies have shown that the higher-quality hay, such as alfalfa, could be fed every other day rather than daily, with similar performance (see Balliette and Torell 1998). Spreading the hay or straw over a large area helps avoid dominance problems.

Younger cattle present even more of a challenge for rice straw diets: their nutritional requirements are higher, their intake capacity is less, and they are generally more finicky eaters. Rice straw can provide a survival ration for younger, growing cattle, but other alternatives, such as culling or feeding diets without rice straw, are usually a better choice.

\section{Rice Straw on Rangelands}

Some cattle producers feed large bales of rice straw free-choice on rangeland by scattering the large bales and cutting the strings. Although some waste occurs, labor is minimized. To reduce waste and increase consumption, some producers inject molasses supplements into the bales. While the amount of supplemental nutrients from the molasses is small, it does enhance the smell and palatability of the straw. In addition, producers may provide supplemental nutrients by using liquid, tub, or block supplements. These supplements have been shown to increase performance of cattle on low-quality forages similar to rice straw, and increased intake and improved digestibility have been noted (see Weyers et al. 2001). The crude protein portion of these supplements is often partially nonprotein nitrogen (NPN), which is about 50 percent efficient in these types of rations compared with natural protein sources. The energy content of the supplement and the complete ration should be a concern, and the cost of the supplement and the labor requirements must also be considered.

\section{FORMULATING RATIONS WITH RICE STRAW AND SUPPLEMENTS}

When formulating rations, consider the nutritional requirements of the livestock (see table 3), and compare the crude protein, TDN, calcium, and phosphorus levels in rice straw and other feedstuffs (table 2) to the cattle's nutritional requirements. Some combination of rice straw with other feedstuffs is needed to formulate a ration that satisfies the animal's nutritional requirements. Often, decisions on whether to use supplements such as liquids, blocks, or tubs compared with supplemental hay is determined by labor and feeding constraints. 
The recommended method to formulate rations with rice straw is using computer programs that specialize in ration formulation. These programs consider all the important factors simultaneously and provide the combination of feeds that best satisfies nutritional, livestock, and economic constraints. However, these programs often require the user to have substantial knowledge about nutrition, and they may not be readily available. Consult with nutrition specialists for additional assistance.

An alternative to using specialized ration programs is using a spreadsheet program that has a template that can assist in trial-and-error calculations. One source of these programs is http://www.ansi.okstate.edu/library/Software.html. Select "Livestock Software - Oklahoma State," then download the "Cowculator" program.

A relatively simple, if old, method of determining the proportion of two ingredients that satisfies a single nutrient requirement is the Pearson Square (see box below). While this method is less flexible than a computer program (the recommended method), it does improve upon simply guessing at proper rations. A free computer program for determining ration formulations that uses the Pearson Square method is available from the agdownload.com Web site (http://www.agdownload.com/html/fld00016.asp).

\section{RATION FORMULATION: ALTERNATIVE APPROACHES}

Specialized computer programs that determine ration formulations are by far the best method for evaluating the use of rice straw as a feed. Another method is using a computer spreadsheet template to facilitate trialand-error calculations. The Pearson Square described below is a noncomputerized method for determining the amount of two feeds that meet a specific nutrient percentage. Although the Pearson Square can give adequate results, feeders are strongly encouraged to use specialized computer programs to evaluate the use of rice straw and to formulate all livestock feeds and rations, since the programs can easily accomodate more than one feed in a ration.

\section{Pearson Square}

Set up the Pearson Square.

(1) Place the desired value for the nutrient in the center of a square (see example on next page).

(2) Place the nutrient composition of two available feed sources on the left-hand corners of the square.

(3) Subtract diagonally across the square and write the result (if it is a negative, enter it as a positive) in the right-hand corners of the square.

Calculate the percentage of the ration each component will contribute.

(4) Total the values on the right side to determine the divisor.

(5) Divide each number in the right-hand corners by the divisor.

(6) Multiply that answer by 100 to get the percentage of that ingredient in the ration.

Determine the weight of feed in the ration.

(7) Estimate dry matter intake (see table 3). Assume a 90\% dry matter basis.

(8) Multiply the dry matter intake (DMI) by the percentage of the ingredient. 


\section{Example}

Consider a dry cow requiring $6.9 \%$ crude protein (CP) in her diet (table 3 ). Rice straw is $4.3 \% \mathrm{CP}$, and a liquid supplement has an effective CP of 19\% (table 2). (The numbers in parentheses below correspond to the steps above.)

(2) Rice straw $4.3 \%$

(2) Liquid supplement 19\%

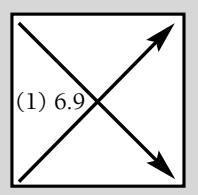

(3) $19-6.9=12.1$

(3) $4.3-6.9=2.6$

(4) $12.1+2.6=14.7$

(5) $12.1 \div 14.7=0.823$

(6) $0.823 \times 100=82.3 \%$

(5) $2.6 \div 14.7=0.176$

(6) $0.176 \times 100=17.7 \%$

(7) DMI for dry cow $=23.1 \mathrm{lb}$

(8) Rice straw amount: $23.1 \mathrm{lb} \times 0.823=19.0 \mathrm{lb}$

(8) Liquid supplement amount: $23.1 \mathrm{lb} \times 0.177=4.1 \mathrm{lb}$

This process can be used for any nutrient, not just crude protein. These amounts, 19.0 and 4.1 pounds, are on a $90 \%$ dry matter basis.

\section{Pearson Square computer software}

A free computer program for determining ration formulations that uses the Pearson Square method is available from the agdownload.com Web site (http://www.agdownload.com/html/fld00016.asp).

\section{DETERMINING THE COST OF RATIONS}

Whichever method you use to formulate rations using rice straw, it is critically important to consider the complete cost of the ration (including transportation, feed processing, and distribution), and not just the low cost of rice straw.

Rice straw is often initially attractive as a low-cost feed; however, the total cost of providing a nutritionally adequate diet must be evaluated. When the complete cost of the ration is calculated, rice straw is sometimes not as inexpensive as it seems. In extreme shortages of feed, however, price or nutritional adequacy may not be issues.

Consider an example using rice straw with a block supplement. A survey by the authors of growers in 2001 found that they paid an average of $\$ 18.50$ per ton for rice straw, and transportation costs averaged $\$ 16.25$ per ton, for a total delivered cost of $\$ 34.75$ per ton. Note that rice straw is often sold by the bale or load, not by the ton. Bale prices were converted to cost per ton to facilitate comparison with hay. Using that cost of straw and the fact that an average milking cow with calf requires 2 pounds of block supplement (\$300/ton) (table 5), the daily feed cost would be about $\$ 0.75$. In this example, the calculation of the total ration cost is as follows.

1. Convert the amount of block supplement from an "as fed" quantity to $100 \% \mathrm{DM}$ (table 2):

\section{$2 \mathrm{lb}$ of block supplement $\times 0.96=1.92$ lb block supplement}


2. Find the amount of rice straw to be included. The total feed consumption of an average milking cow with calf is $27.4 \mathrm{lb}$ on a $100 \%$ DM basis (table 5). Subtract the portion of block supplement:

\section{$27.4 \mathrm{lb}$ total consumption $-\mathbf{1 . 9 2} \mathrm{lb}$ supplement $=\mathbf{2 5 . 4 8} \mathrm{lb}$ rice straw}

3. Convert the rice straw to pounds as fed:

\section{$\mathbf{2 5 . 4 8} \mathrm{lb}$ rice straw $\div \mathbf{0 . 9 0}=\mathbf{2 8 . 3} \mathrm{lb}$ rice straw}

4. Find the cost per day of rice straw. Rice straw costs $\$ 0.0173 / \mathrm{lb}(\$ 34.75 \div 2,000 \mathrm{lb})$ :

\section{3 lb rice straw $\times 0.0173=\$ 0.48$.}

5 . Find the cost per day of block supplement. Block supplement costs $\$ 0.15 / 1 b$ ( $\$ 300$ $\div 2,000$ ):

\section{2 lb block supplement $\times \$ 0.15=\$ 0.30 /$ day}

6. Find the cost of the total ration:

$\$ 0.48+\$ 0.30=\$ 0.78 /$ cow $/$ day.

This is a laborious effort that evaluates only a single ration. A more complex example would be highly laborious: for example, how much would it cost to feed more of the same supplement, a different supplement, or purchase a better quality forage? This illustrates that the best method to evaluate the cost-effectiveness of rations is a specialized computer program.

Some ranchers calculate rations by cost per month so they can compare this cost to leasing winter pasture. In the above example, convert ration cost per day to cost per month by multiplying it by 30 days $(\$ 0.75 \times 30=\$ 22.50)$.

Although rice straw is relatively inexpensive, the total cost of the ration is about triple the cost of the straw (without transportation). Generally, rice straw is most appropriate for cattle with relatively low nutritional requirements, such as dry cows or low-milking cows, or when supplements are not expensive. Specific circumstances vary, and the appropriateness of rice straw must be evaluated individually and from year to year.

\section{CHEMICAL RESTRICTIONS ON FEEDING RICE STRAW}

Rice production includes the use of herbicides and, to a lesser extent, pesticides and desiccants. Although none of these are known to have toxicological hazards to livestock via rice straw, because the research has not been completed to meet government label requirements, some regulations prohibit the use of the straw for livestock feed (http://www.ricestraw.org/restrictions-ricestraw.html). Rice producers or hay brokers who market rice straw treated with chemicals that restrict the use of rice straw as cattle feed should not offer such straw as feed. Cattle feeders should ask the producer or broker about herbicide and pesticide use in the field where the straw was grown. 


\section{B IBLIOGRAPHY}

Balliette, J., and R. Torell. 1998. Alfalfa for beef cows. Cattle Producer's Library, CL 319. http://www.unce.unr.edu/publications/Spec\%20Pubs/CL-319.htm

Garrett, W. N. 1978. The value of rice straw compared to alfalfa hay for feedlot diets. Proc. Western Section Amer. Soc. Anim Sci. 29:375-378.

Garrett, W. N., and J. R. Dunbar. 1992. Rice straw as a feedstuff for ruminant livestock. Unpublished report. Department of Animal Science. University of California, Davis, CA.

Hess, B., L. J. Krysl, M. B. Judkins, K. K. Park, B. A. McCracken, and D. R. Hanks. 1992. Supplementation of cattle grazing dormant intermediate wheatgrass pasture. Proc. West. Sec. Amer. Soc. Anim. Sci. 43:70.

Hull, J. L., J. R. Dunbar, and J. G. Morris. 1972. Wintering steer calves on rations high in rice straw. Cal. Agric. 26(11):14-15.

Nader, G. 1999. Rice straw utilization by cattle. Report to the Rice Research Board. December. http://www.syix.com/rrb/99rpt/StrawUtil.htm

Nader, G. 2000. Rice straw utilization by cattle. Report to the Rice Research Board. December. http://www.syix.com/rrb/00rpt/StrawCattle.htm

Nader, G., J. Williams, and R. Ingram. 1998. New concepts of rice residue for use as cattle feed. Report to the Rice Research Board. December. http://www.syix.com/rrb/98rpt/Cattle.htm

National Research Council. 1984. Nutrient requirements of beef cattle. 6th rev. ed. Washington, D.C.: National Academy Press.

Weyers, J. S., H. T. Purvis II, C. R. Krehbiel, D. L. Lalman, and D. A. Cox. 2001. Comparison of dry and liquid protein supplements fed to stocker cattle consuming low-quality native grass: Performance and digestibility. Oklahoma State University, Divison of Agricultural Science and Natural Resources, Oklahoma Agricultural Experiment Station Publication P986. http://www.ansi.okstate.edu/research/2001rr/20/20.htm 


\section{FOR MORE INFORMATION}

You'll find more information on cattle production in the following ANR sources:

Factors Affecting the Cattle Producer's Income, Publication 2313, 1980.

Feed Guide for Growing and Finishing Cattle,, Publication 2248, 1970.

Also see:

Trace Minerals for California Beef Cattle, University of California Cooperative Extension Web site: http://animalscience.ucdavis.edu/Projects/MineralProject/

University of California Alfalfa Workgroup's "California Alfalfa and Forages" Web site (http://alfalfa.ucdavis.edu/).

agdownload.com Web site (http://www.agdownload.com/html/fld00016.asp).

Visit our online catalog at http://anrcatalog.ucdavis.edu. You can also place orders by mail, phone, or fax, or request a printed catalog of publications, slide sets, CD-ROMs, and videos from

University of California

Agriculture and Natural Resources

Communication Services

6701 San Pablo Avenue, 2nd Floor

Oakland, California 94608-1239

Telephone: (800) 994-8849 or (510) 642-2431, FAX: (510) 643-5470

E-mail inquiries: danrcs@ucdavis.edu

An electronic version of this publication is available on the ANR Communication Services Web site at http://anrcatalog.ucdavis.edu.

Publication 8079

(C) 2002 by the Regents of the University of California, Division of Agriculture and Natural Resources. All rights reserved.

Funding for this research has been made possible by the California Rice Research Board.

The University of California prohibits discrimination against or harassment of any person employed by or seeking employment with the University on the basis of race, color, national origin, religion, sex, physical or mental disability, medical condition (cancer-related or genetic characteristics), ancestry, marital status, age, sexual orientation, citizenship, or status as a covered veteran (special disabled veteran, Vietnam-era veteran or any other veteran who served on active duty during a war or in a campaign or expedition for which a campaign badge has been authorized). University Policy is intended to be consistent with the provisions of applicable State and Federal laws.

Inquiries regarding the University's nondiscrimination policies may be directed to the Affirmative Action/Staff Personnel Services Director, University of California, Agriculture and Natural Resources, 300 Lakeside Drive, 6th Floor, Oakland, CA 94612-3550 (510) 987-0096. For a free catalog of other publications, call (800) 994-8849. For help downloading this publication, call (530) 754-5112.

pr-9/02-SB/VFG

ISBN 978-1-60107-255-9

This publication has been anonymously peer reviewed for technical accuracy by University of California scientists and other qualified professionals. This review process was managed by the ANR Associate Editor for Animal, Avian, Aquaculture, and Veterinary Sciences. 